\title{
Nucleic Acid-Based Pathogen Detection in Applied Plant Pathology
}

Among the tools available for pathogen detection, nucleic acid (NA)-based techniques are widely recognized as some of the most powerful. NA-based detection techniques, particularly those that rely on the polymerase chain reaction (PCR), typically are rapid, specific, and highly sensitive $(24,39,62)$.

Research in subdisciplines upon which applied plant pathologists depend-etiology, epidemiology, and diagnosis-heavily utilizes NA-based detection techniques, with their use greatly outnumbering the use of immunoassays in recent research publications (2). Applied plant pathologists recognize that NA-based techniques have an increasingly important place in our own laboratories to address applied questions, and implementation of these techniques in Extension and other applied programs increases yearly. However, proper implementation of these techniques poses challenges, ranging from the significant cost of the technology to the need to understand the techniques well enough to be able to interpret and troubleshoot anomalous laboratory results.

\section{NA-Based Techniques}

PCR and other NA amplification techniques. The polymerase chain reaction (PCR) - the exponential amplification of a target DNA strand catalyzed by a thermostable DNA polymerase-has become the foundation of NA-based pathogen detection (Fig. 1). Although culture-based methods and enzyme-linked immunosorbent assay (ELISA) are still fundamentally valuable techniques, PCR commonly is more sensitive than either $(6,13,23,84,85$, $92,106)$, although exceptions exist $(85,97)$. PCR detection is also usually completed

Corresponding author: Paul Vincelli, Department of Plant Pathology, University of Kentucky, Lexington; E-mail: pvincell@uky.edu

doi:10.1094/PDIS-92-5-0660

(c) 2008 The American Phytopathological Society more rapidly than culture techniques $(38,59,72,113)$. Even RNA-based viruses can be detected via PCR, by first reversetranscribing the RNA into DNA (85).

Real-time PCR (Fig. 2) allows for DNA amplification via PCR as well as detection of the amplified DNA fragment (the amplicon) within the same, sealed reaction vessel $(62,69,85)$. In real-time PCR, the amplicon is detected through the use of oligonucleotide probes which emit fluorescence of defined wavelengths in proportion to the amount of amplicon present after each thermocycle. Real-time PCR protocols are among the most rapid speciesspecific detection techniques currently available $(14,30,78,86,112)$. Although more costly, real-time PCR offers several advantages over conventional PCR, including: the provision of data in real-time, a much greater quantitation range, greater sensitivity, reduced risk of sample contamination during PCR setup due to laboratory contamination with amplicon, and a greater amenity to multiplexing (simultaneous testing for multiple pathogens) $(14,64,85,106)$. Real-time PCR protocols have been implemented in the field using portable real-time PCR machines for same-day, on-site results $(64,86)$.

PCR is widely recognized as a highly sensitive technique; detection of the DNA from as little as a single spore is possible $(62,110)$. However, its sensitivity can be increased in several ways. One common way is through selective enrichment of the pathogen in media prior to molecular testing $(27,35,70,84,92)$. Another is nested PCR, where two rounds of PCR are performed, the second using a primer set internal to those used in the first round $(8,29,36,71)$. Immunocapture can be used to concentrate pathogen cells prior to PCR, thus increasing detection sensitivity (56). A relatively new molecular tool that can increase detection sensitivity is multiple displacement amplification (MDA) $(3,22$, 33,73). MDA exponentially amplifies DNA using random hexamer primers, resulting in more or less complete genome amplification for essentially all DNA present in the sample (Fig. 3). By performing MDA prior to PCR on a sample containing trace amounts of pathogen genomic DNA, one can exponentially increase its quantity, potentially increasing the likelihood of pathogen detection. Furthermore, MDA can be used to generate large quantities of genomic DNA from very limited samples (single nematodes, single fungal spores, etc.), thus providing a supply of genomic DNA that can be used for multiple tests and/or stored for future use (91).

Although PCR is by far the most important method for nucleic acid amplification in microbial detection, other methods do exist, and several should be mentioned. Loop-mediated isothermal amplification (LAMP) offers levels of sensitivity and selectivity equivalent to PCR without the requirement for a sophisticated thermocycler $(50,67)$. Similarly, the ligase chain reaction does not require a thermocycler to amplify a selected target sequence (64). Although commonly used in clinical settings for human pathogens, the ligase chain reaction has been applied in relatively few plant pathosystems $(53,60,64)$. DNA amplification is an area of much activity with frequent technical advances, and new techniques will likely be developed in the near future.

RFLP and AFLP. Restriction fragment length polymorphisms (RFLP) of DNA representing selected genes can be used to identify pathogen species $(16,59,98)$. This approach to species identification depends on having an excellent database on the variability in fragment length polymorphisms that may be found among isolates of individual species, since conspecific isolates may differ in the presence or absence of particular restriction sites, consequently changing the RFLP banding profile (59).

Amplified fragment length polymorphism (AFLP) (Fig. 4), a modification of the RFLP technique, has been used for species identification $(32,96)$ and more commonly to examine genotypic diversity within a population $(9,43)$. The latter attribute is useful in discerning the geo- 
graphic origin of pathogens associated with new disease outbreaks, as in the case of sorghum ergot (101). Although AFLP analysis is a powerful diagnostic tool, it is laborious, technically demanding, and not suitable for routine use in diagnostic clinics.

Arrays. Oligonucleotide arrays offer greatly expanded multiplexing capability compared to conventional PCR, real-time PCR, and other more widely used techniques $(28,52-54)$. Arrays consist of discrete spots of pathogen-specific oligonucleotide sequences immobilized onto a solid surface such as a nylon membrane or glass slide. The sample DNA is amplified by PCR, labeled, then hybridized to the array (Fig. 5). Because the sample DNA is amplified by PCR, sensitivity of arrays is typically high, and the number of pathogen-specific tests that can be run on the array is essentially unlimited. As an example of the power of the technique, Tambong et al. developed a macroarray that simultaneously tests for the presence of most known Pythium species (99). Having the capability to use arrays to simultaneously test diseased plant tissue for dozens or hundreds of pathogens would be most useful in cases when the diagnostician may not know which species-specific detection assay to apply. Arrays will also be valuable because plants are often infected with several pathogens, some of which may act in concert to cause a disease complex. Macroarrays may be more useful in plant disease diagnosis than microarrays because of their greater sensitivity and freedom from the need for highly specialized equipment (54). While arrays are superior for multiplexing, they are not well-suited for quantitation (12) and may be limited when high-throughput assays are required.

Sequencing. PCR amplicons can often be sequenced relatively inexpensively and rapidly, given the availability of automated sequencers in many laboratories (Fig. 6). Amplicons can be prepared for direct sequencing relatively easily using a commercial kit for purifying directly from the PCR reaction mixture or from agarose if gel purification is needed to separate the target amplicon from others formed during the PCR. Genetic databases available on the internet such as GenBank allow rapid comparison of one's sample sequence to extensive and growing libraries of sequences. Cloning of an amplicon is an option as well, especially if sequence quality obtained by direct sequencing is inadequate (Fig. 6B), though cloning is a much more laborious process.

Routine sequencing is likely to play an increasingly important role in species identification, through the application of DNA bar-coding. This concept-currently still being researched-involves the use of sequence from a single piece of proteincoding DNA for rapid identification of any organism to the species level $(37,63,75)$.

\section{Common PCR Targets and Specificity}

For fungal, bacterial, and nematodal pathogens, ribosomal RNA genes and in- tervening sequences are common targets for PCR amplification $(10,13,62,98)$. The internal transcribed spacer (ITS) regions of ribosomal genes are especially useful tar-

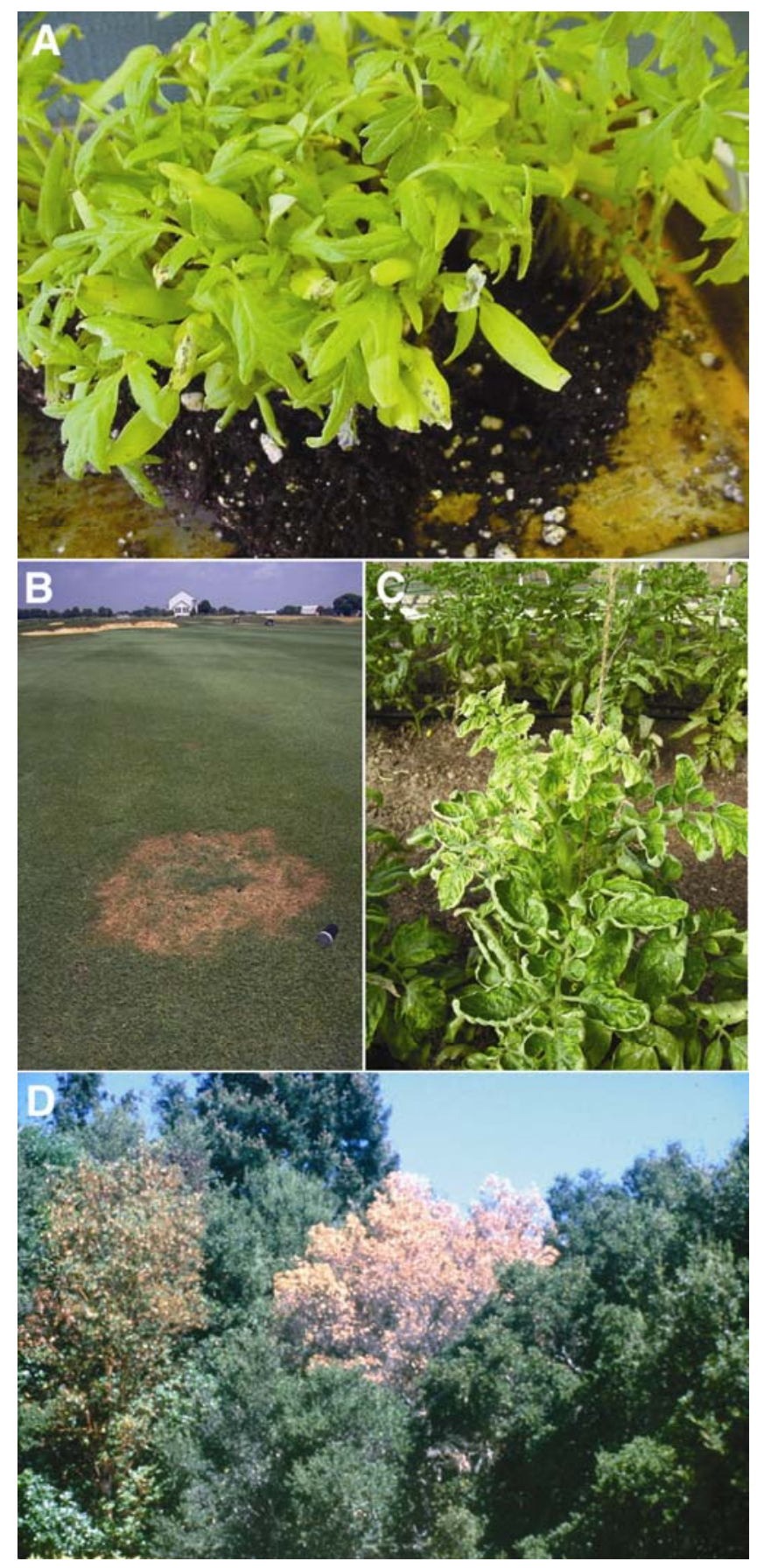

Fig. 1. A, Is the necrotic spotting on cotyledons of these tomato transplants due to bacterial spot? Because of its destructiveness in Kentucky's climate, a positive diagnosis would result in a recommendation to destroy the transplants. A polymerase chain reaction (PCR)-based test permits same-day diagnosis, permitting a producer to know quickly whether the transplants can be safely used. B, Traditional culture techniques for high-confidence diagnosis of take-all, a root disease of creeping bentgrass, can take so many weeks to complete that they are not performed on most samples. Therefore, diagnosis of this disease is typically based on presumptive evidence obtained by microscopic examination of roots. However, PCR allows a positive diagnosis quickly, allowing for more rational use of fungicides when appropriate. C, PCR allowed quick determination that the Kentucky outbreak shown in this photograph was due to Tomato yellow leaf curl virus, providing a defensible basis for recommending immediate destruction of this greenhouse crop. D, Phytophthora ramorum causes varied symptoms on hosts, ranging from lethal cankers and associated mortality (shown here) on certain oak species, to nearly benign leaf spots on other woody species. PCR is central to regulatory efforts to detect and eradicate this pathogen (21). 
gets for species-specific primers for several reasons: (a) their high copy number increases detection sensitivity; (b) they may offer sequence variability among pathogen species, facilitating discovery of primers unique to particular pathogen species or subspecies; and (c) sequences for primer design can be readily obtained by first amplifying ITS regions using universal primers that target the conserved portions of ribosomal DNA that flank the ITS regions $(10,24,109)$. The use of ITS sequences as a component of fungal identification is becoming increasingly common.

Mitochondrial genes such as cytochrome oxidase genes are also suitable targets for distinguishing pathogen species $(58,75)$. Like ribosomal genes, mitochondrial genes are attractive targets because they are present in high copy number and present in both rapidly evolving and conserved regions that facilitate the development of species-specific primer sets.

Some closely related pathogen species are poorly resolved with certain targets. For example, certain Phytophthora species cannot be readily distinguished based on ITS sequences and others are not distinguished using mitochondrial cox II genes $(15,58)$.

In bacteria, $h r p$ genes are important to pathogenicity and can serve as useful PCR targets $(6,46,51,56,61)$. Tests that target pathogenicity genes are particularly valuable for detecting pathogen species that contain nonpathogenic strains (54). Genes encoding secondary metabolites that function as virulence factors also are useful PCR targets $(5,19,87,93)$, although this approach is risky if epidemiologically

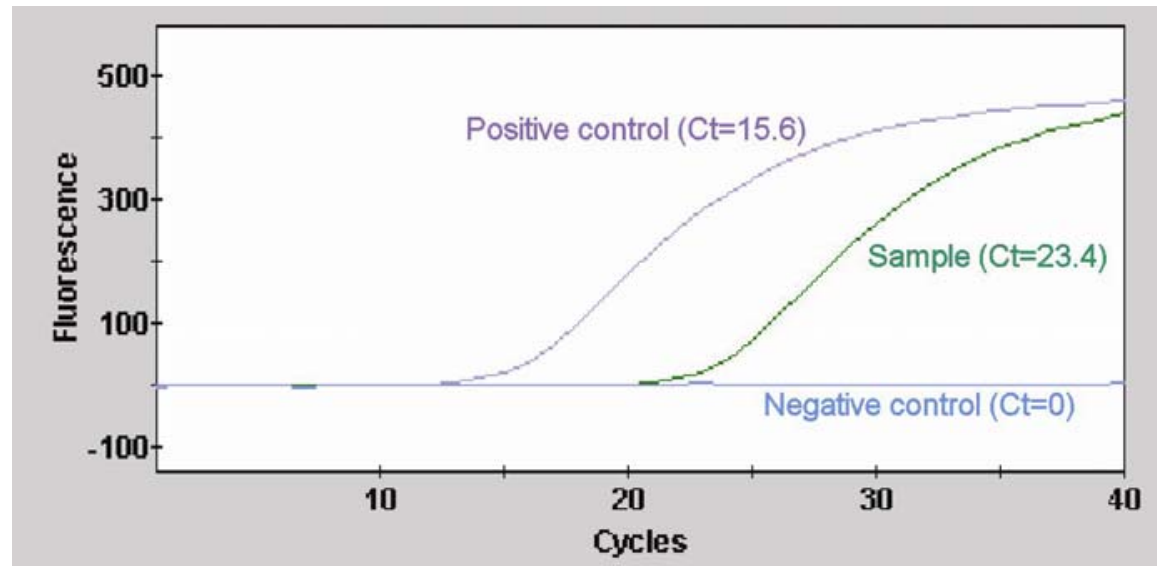

Fig. 2. Fluorescence curves from a real-time polymerase chain reaction (PCR) pathogen experiment for detecting Xylella fastidiosa. "Ct" indicates cycle threshold, the thermocycle in which fluorescence in a reaction vessel statistically exceeds background levels, indicating a positive reaction. In this figure, a positive reaction was detected in the positive control and in the sample at $\mathrm{Ct}=15.6$ and $\mathrm{Ct}=23.4$, respectively.

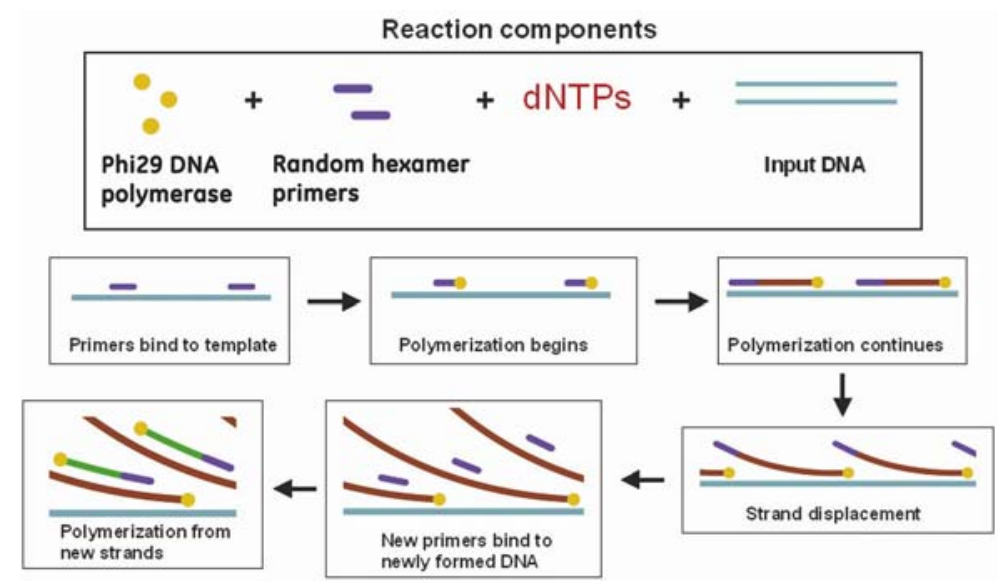

Fig. 3. Multiple displacement amplification (MDA) of DNA. @2007, General Electric Company. Used with permission. In an MDA, reaction components are mixed and incubated isothermally, typically at $30^{\circ} \mathrm{C}$. During this reaction, random hexamer primers anneal with DNA present in the sample. This is not a pathogen-specific priming; primers will bind with any DNA present in the sample. Once primers are annealed, complementary strands of DNA begin to polymerize, catalyzed by Phi29 DNA polymerase. As these new DNA strands form, they become displaced from the original DNA strand, thus becoming available to anneal with the hexamer primers, resulting in polymerization of more strands. New strands become displaced and primers anneal with them, fueling exponential amplification of the original DNA template. important strains do not possess the target gene (80).

NA-based tests are often designed for detection of particular pathogen species. However, NA-based tests may also be designed to detect or discriminate biotypes below the rank of species $(56,70,79$, $88,107)$. Conversely, NA tests capable of detecting taxa above the level of species can also be very valuable when testing broader hypotheses than species-specific primers and probes allow: as an example, a diagnostician may want to test the hypothesis that a particular plant is infected with a phytoplasma species. These can be useful when the diagnostician is uncertain which species may be involved $(18,36)$.

\section{Benefits and Limitations of NA-Based Techniques}

Benefits and selected applications. There is no debate about the value of NAbased techniques to applied plant pathology programs. The advantages of rapidity, high sensitivity, specificity, and the ability to quantify pathogen biomass are indisputable. Some examples of the application of NA-based tests are as follows.

- Rapid detection and identification of pathogens for which traditional tech-

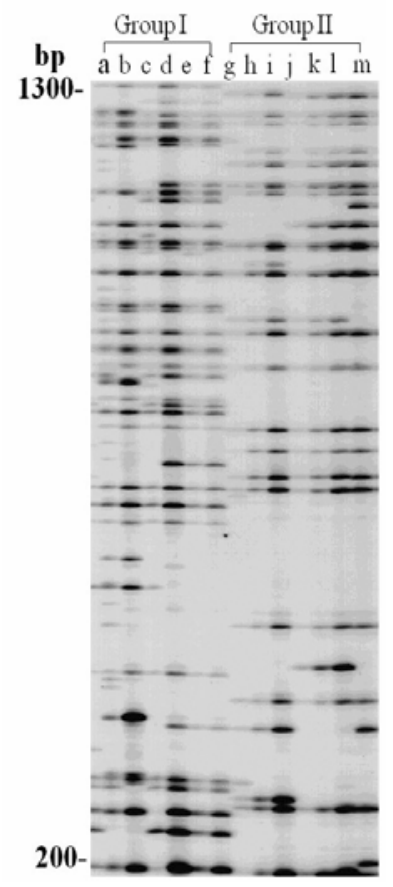

Fig. 4. Genetic similarity among isolates of Ophiosphaerella narmari, a cause of spring dead spot of bermudagrass, based on amplified fragment length polymorphisms (AFLPs) using the selective primer pair EAA/MCA. Australian (a-c) and Californian (d-f) isolates in group I have a similar banding pattern and are genetically distinct from group II isolates collected in Oklahoma (g-l) and Kansas (m). The similarity in banding patterns among Australian and Californian isolates also suggests a common point of origin. From Wetzel, 1999 (108). 


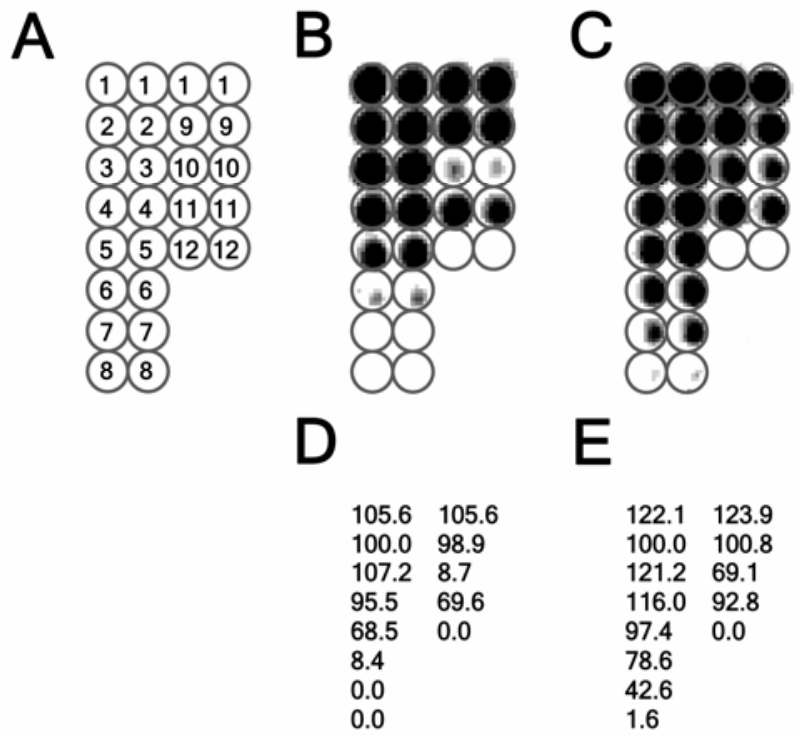

Fig. 5. Detection and quantification of fungal DNA utilizing a DNA macroarray. A, Scheme for the layout of pathogen-specific oligonucleotide detectors immobilized on a nylon support. Sample DNA is amplified by polymerase chain reaction (PCR) using consensus or universal primers. Amplified DNA is labeled and hybridized to the array, resulting in darkened spots where hybridization occurs. Note that each oligonucleotide is represented by two side-by-side replicates. Detector oligonucleotides spotted are as follows: $\mathbf{1}$ = a positive control for hybridization; $\mathbf{2}$ = a labeled reference oligonucleotide for detection and calibration; $\mathbf{3}$ to $\mathbf{8}=\mathbf{a}$ dilution series of a universal oligonucleotides for detecting fungi (absolute quantities are 8.0 [3], 2.0 [4], 0.5 [5], 0.2 [6], 0.1 [7], and $0.02 \mathrm{fmol} / \mathrm{spot}$ [8]); 9 = a detector oligonucleotide for exogenously added control DNA; 10 and 11 = detector oligonucleotides (spotted at $8.0 \mathrm{fmol} / \mathrm{spot}$ ) for Fusarium solani and Verticillium albo-atrum, respectively; 12 = the reference oligonucleotide for detection and calibration [used in 2] but synthesized without label and spotted as a negative control. B, Signals obtained upon hybridization of amplicons resulting from co-amplification of $50 \mathrm{pg}$ of $F$. solani genomic DNA and $5 \mathrm{ng}$ of $V$. albo-atrum genomic DNA. C, Signals obtained upon hybridization of amplicons resulting from co-amplification of $5 \mathrm{ng}$ of $F$. solani genomic DNA and $5 \mathrm{ng}$ of $V$. albo-atrum genomic DNA. D and E, Quantification of hybridization signals obtained in B and C, respectively. Hybridization signal strength is reported relative to the average integrated optical density of a labeled reference control, marked 2 in panel A. Illustration from Lievens and Thomma (54). niques are inadequate or nonexistent, such as:

(i) obligate parasites, especially in complex environmental samples-VA mycorrhizae, for example (39);

(ii) species that are difficult to identify by microscopy without considerable expertise, such as Meloidogyne spp. (95);

(iii) organisms that grow slowly or fail to sporulate in culture (100);

(iv) species that are morphologically similar to related nonpathogenic species (72);

(v) life stages that are immature, such as nematode eggs or juveniles (75).

- Detection and identification of pathogens of potential regulatory concern or of high economic consequence $(8,42,75,102)$. Important examples of pathogens where molecular detection is a fundamental tool include Phytophthora ramorum, the cause of sudden oak death (42,102); Xanthomonas citri strains causing citrus canker (61); and Tilletia indica, cause of Karnal bunt of wheat (31). Discrimination of the Asian soybean rust pathogen, Phakopsora pachyrhizi, from the related species Phakopsora meibomiae by PCR (30) is central to soybean rust management programs in the United States.

- Quantification of pathogen biomass in host tissue or in environmental samples $(62,64)$.

- Determining the geographic origin of, or genetic relationships among, pathogen strains (17).

- Documenting the existence and relative importance of latent infections. Com-
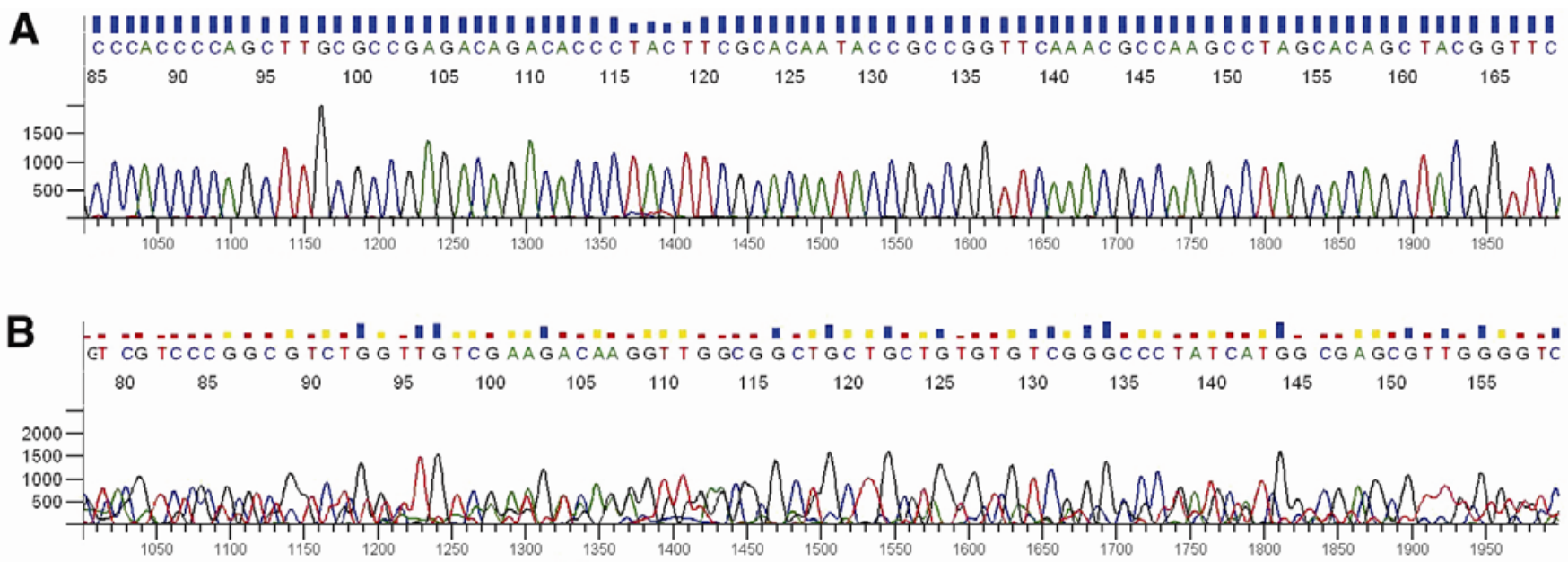

Fig. 6. Chromatograms provided by an automated sequencer for determination of the nucleic acid sequence of two polymerase chain reaction (PCR) amplicons following purification to remove PCR reagents. A, Illustration of a nucleotide sequence of high quality, with uniformly spaced peaks having little background noise. The nucleotide called by the automated sequencer is indicated above each peak. The statistical quality of each called base (the Phred score) is indicated by a color-coded bar above each base; a Phred score of 20 (a probability of $\mathbf{0 . 0 1}$ of an incorrect base call) or higher is indicated by a tall blue bar. B, Illustration of a nucleotide sequence of low quality, with many superimposed peaks and substantial noise. The poor quality is also reflected in low Phred scores, coded by this software in short bars of either red or yellow. This particular sequencing result might be due to the presence of a mixture of two or more distinct DNA sequences of similar lengths amplifying in the PCR reaction, resulting in a mixture of amplicons being sent for sequencing. If so, cloning the separate sequences would be the best way to obtain high-quality sequence of the two amplicons. 
bined with histological evaluations, NAbased techniques can be used to discriminate limited, dormant infection in asymptomatic tissues from active host colonization by the pathogen (29).

- Detection of bacteria that have entered a viable but nonculturable state (34).

- Early season detection of pathogens in airborne primary inoculum (62), without the requirement of personnel skilled in morphological identification of fungi.

- Pathogen testing for certification and host indexing programs $(60,107)$.

- Detection and quantification of seedborne pathogens $(6,35,71)$.

- Monitoring of pathogen biotypes that are particularly aggressive or that represent discrete races $(62,64,107)$.

- Detection of fungicide resistance $(47,76,115)$, including quantification of fungicide resistance alleles in a pathogen population (62).

- Assessing the potential risk for storage decay in a harvested commodity (4).

- Monitoring pathogen biomass and host colonization (41), including in breeding programs, in order to distinguish host tolerance from host resistance (20).

Cautions and caveats. There is a multitude of review papers on the subject of NA-based techniques for detection of microorganisms, and the strengths of these techniques are well-documented and welldescribed. Fewer reviews explicitly discuss limitations in detail, but in order to use NA-based detection tools effectively, users must understand these, as well. Some of these limitations are widely recognized and may be more or less readily addressed; other limitations are inherent to the technique and must be acknowledged in order to critically interpret laboratory results.

False negatives and positives resulting from incomplete specificity. It is critical for users of NA-based tools to recognize that primers and probes do not exhibit perfect specificity for the target pathogen-and exclusively that pathogen -in every assay. Not all naturally occurring variants or clades may be represented in the initial isolate collection used to develop a set of primers, which can lead to false negatives by PCR $(12,19,88,103)$. Mutations at the primer-binding site-even a single-base mismatch-may prevent DNA amplification $(90,111)$. Conversely, false positives can occur when a primer set designed to be species- or strain-specific cross-reacts with other species or strains $(7,21,31,45,60$, $86,103,107)$. Incomplete specificity is not unique, of course, to NA-based tests, but it is critical to be cognizant of this possibility whenever these tests are used. Under the premise that two lines of evidence are stronger than one, NA-based pathogendetection protocols are strengthened when they are based on molecular markers or primers developed for at least two independent regions of the genome. This seems especially important for high-consequence pathogens, particularly if non-NA-based lines of evidence for pathogen detection are limited or lacking. When published NA techniques do not meet this standard, their results must be interpreted with some caution.

The confidence of diagnosticians in the specificity of a primer set can increase in proportion to the size of the database used to develop and validate it. Ideally, a primer set should be developed using sequences from many isolates representing a wide geographic range for the pathogen of interest. While it is virtually impossible to have a complete representation of a pathogen population, prior phylogenetic studies to assess relationships among strains help to assure that all known clades are represented in the sequence alignments used to select primers. Ideally, primer sets should be validated by testing against (i) isolates of the target pathogen, (ii) a wide variety of related microbial species, and (iii) unrelated microbial species commonly associated with the host tissue likely to be tested. Ideally, positive reactions will be consistently observed in the first group and never in the second and third groups.

Sample collection. In the clinical microbiology lab, collection of an appropriate sample is regarded as "the most important step in the testing process" (14), and the same is true for plant disease diagnosis. Since only 1 to $2 \mu \mathrm{l}$ of a sample extract is typically used in an NA-based test, great care must be exercised in assuring that the extract is prepared from carefully selected, representative tissue samples most likely to be colonized by the pathogen(s) of concern (2). Furthermore, although multiplexing capabilities are increasing greatly, especially through microarrays, a single global test for plant pathogens will not be possible when different tissues are required to test for different pathogens. At a minimum, one might need a root assay, a lower stem assay, and a foliar assay in order to test for a wide variety of known pathogens. However, since different pathogens often colonize different tissues and portions of plant organs (1), one might need to separately process and test several samples even if they are collected from the same organ.

Current survey protocols for $P$. ramorum, the cause of sudden oak death, illustrate potential sampling problems for NA tests. This oomycete causes destructive bleeding cankers on members of the Fagaceae, but may also cause foliar spotting, foliar blighting, and/or twig dieback on a wide variety of plant species $(21,104)$. Furthermore, $P$. ramorum may infest the potting mix of nonsymptomatic or noninfected plants in the nursery $(11,55)$. Thus, when testing to determine whether $P$. ramorum is present in a nursery, a surveyor may need to collect and test a variety of samples of symptomatic plant materials as well as soil in order to ensure the best possible chance of detection if the pathogen is present.
Contamination risks. Because the amplification of target DNA that occurs in PCR is exponential, the technique is extremely sensitive to contamination $(24,54,56)$. This highlights the need for excellence in the documentation and execution of laboratory practices as well as inclusion of proper controls in all assays (26). Each run should include a negative control that receives water instead of template as well as a positive control that contains DNA of a strain known to react positively.

$P C R$ inhibition. Organic and inorganic compounds present in host tissues, components of microbial cells, and other materials can all inhibit PCR $(56,97,107,111)$. Therefore, it is critical to include appropriate controls with each sample in order to assure that a negative result is not due to the presence of PCR inhibitors in the reaction tube $(71,111)$. Either of two general approaches can serve this purpose: a parallel control, in which a duplicate reaction vessel containing an aliquot of sample is "spiked" with the DNA of a known positive strain (90); or an internal control, where the reaction mixture is a multiplex that includes a primer set for the pathogen being tested as well as a primer set that detects a host gene, such as a cytochrome oxidase gene $(106,107)$ or host ITS gene (6). Failure of the parallel or internal control to amplify efficiently indicates PCR inhibition has occurred (Table 1).

Practices for mitigating PCR inhibition are varied and include: minimizing host tissue pieces used in DNA extraction, sample dilution 10- to 1,000-fold, concentration of pathogen cells by centrifugation, immunocapture or agar-adsorption to separate pathogen cells from chemical inhibitors, addition of inhibitor-binding agents, pathogen enrichment on selective media prior to PCR, and other practices $(27,49,56,57,61,70,111)$. While the diagnostician should always be aware of the possibility of PCR inhibition, it is readily addressable if appropriate controls that permit its detection are included in each assay.

PCR-positive, but is it viable? PCRbased tests do not distinguish viable sources of DNA template from nonviable ones-all will amplify in the reaction vessel. However, technical solutions exist to obviate this problem, such as pretreatment of samples with ethidium monoazide, which penetrates dead cells (but not live cells) and binds covalently to DNA, preventing PCR amplification $(66,83)$. Other techniques to enhance detection of live cells include selective enrichment of the pathogen on media prior to $\operatorname{PCR}(54,84)$ and using reverse-transcriptase PCR (RTPCR) to amplify mRNA, which is associated with viable cells (90). The problem of false positives arising from dead pathogen cells is not unique to PCR, as similar results can be obtained with immunoassays $(25,44)$. 
Other. The possibility of false negatives resulting from DNA polymorphisms among conspecific isolates was discussed above, but there are other potential causes of such errors, as well. For example, a false negative may result if the pathogen is only present as resistant resting structures from which DNA may not be readily extractable, such as oospores (60). If that possibility exists, steps to enhance sensitivity, as discussed above, may be appropriate. False negatives may also occur as infected tissues age in the field, since pathogen populations may decline and secondary organisms may invade (19). Finally, hybridization between related pathogen species can complicate NAbased diagnostics $(15,59)$.

\section{Implementing NA-Based Detection Techniques}

NA-based pathogen detection techniques can and should be used more widely in plant diagnostic labs for several purposes:

(i) To provide a more defensible diagnosis. For certain diseases, traditional techniques work well, but for other diseasesor if there is a possibility of litigation related to the diagnosis-a molecular test provides important evidence in support of the diagnosis.

(ii) To speciate pathogens. Many plant pathologists do not have sufficient training to readily speciate important pathogen genera like Pythium or Phytophthora by morphological examination. However, once competence is obtained with sequencing, one can obtain species designations for a wide variety of microorganisms, even if they are nonsporulating.

(iii) To contribute to development of a genomics database. Diagnosticians and other applied plant pathologists are in a unique position to augment the genomic database for plant pathogens because of their exposure to a broad range of pathogens on highly diverse hosts. Many of these pathogens are cultured during the diagnostic process, and sequencing of the ITS or mitochondrial genes could help provide a molecular fingerprint for numerous plant pathogens. An example of this type of program is currently underway in Canada, where DNA of several hundred Pythium isolates is being amplified and categorized using ITS and mitochondrial cox II primers (C. A. Lévesque, personal communication).

While NA-based tests should and will become increasingly more widely used, they must be employed with circumspection. Like all sophisticated laboratory techniques, NA-based tests have the potential to yield false positives and false negatives. Therefore, plant pathologists cannot and should not rely exclusively on a single NAbased test as the sole evidence for first reports nor for other critical samples. Other lines of evidence-microscopy, culturing, ELISA, NA-based tests using primer sets designed for different targets in the genome, or other detection techniques - should be obtained in such cases.

Diagnosticians are accustomed to seeking evidence in proportion to the needs of the particular case. For example, a single symptomatic shrub in a home landscape usually does not receive the same laboratory workup as a sample representing an epidemic in a 100-ha field of a commercial crop. Depending on the need for accuracy and the circumstances of the particular case, a positive PCR test may not be sufficient evidence for a high-confidence diagnosis; verification of the identity of PCR amplicons generated using species-specific primers is sometimes advisable. As examples, verification would be prudent for the first application of a new NA-based test in one's laboratory, in cases that might have regulatory or litigious consequences, or in cases of particularly high economic impact. Techniques for verifying amplicon identity include analysis of restriction fragment length polymorphisms (16,51, $68,98)$, sequencing $(21,48)$, or hybridization to a taxon-specific DNA probe (19).

There are practical limitations in implementing NA-based detection techniques in typical plant diagnostic laboratories which must be addressed. The cost of equipment and reagents is not trivial (60), and cost calculations should include the cost of staff support. Diagnosticians often are too occupied during the diagnostic season to conduct these kinds of tests themselves, unless such tests are available in highly simplified protocols or commercial kits. Furthermore, personnel who conduct a variety of NAbased assays need significant training or close supervision for quality-control purposes. The accumulation, storage, and record-keeping of primers as well as live reference cultures add new dimension to needs for laboratory space, facilities, and staff support. Thus, the costs of laboratory supplies and equipment, coupled with the

Table 1. Real-time polymerase chain reaction (PCR) assay, testing for Serratia marcesens in undiluted and diluted DNA extracts from vascular bundles of field-grown watermelon

\begin{tabular}{lcllc}
\hline & & \multicolumn{2}{c}{ Aliquots added to reaction tube } \\
\cline { 3 - 5 } Assay no. & Reaction no. & Sample DNA & Controls $^{\mathbf{a}}$ & $\mathbf{C t}^{\mathbf{b}}$ \\
\hline 1 & 1 & None & Water & 0 \\
1 & 2 & None & Known & 27.5 \\
1 & 3 & WM3-1,44, undiluted & - & 38.2 \\
1 & 4 & WM3-1,44, undiluted & Known & 38.5 \\
1 & 5 & WM47, undiluted & - & 0 \\
1 & 6 & WM47, undiluted & Known & 37.6 \\
2 & 7 & None & Water & 0 \\
2 & 8 & None & Known & 24.5 \\
2 & 9 & WM3-1,44, diluted & - & 29.5 \\
2 & 10 & WM3-1,44, diluted & Known & 26.6 \\
2 & 11 & WM47, diluted & - & 38.9 \\
2 & 12 & WM47, diluted & Known & 28.9 \\
\hline
\end{tabular}

a "Water" indicates addition of sterile molecular biology-grade water. "Known" indicates addition of $100 \mathrm{pg}$ of genomic DNA extract from Serratia marcesens isolate 103. "-" indicates that neither "Water" nor "Known" was added.

b $\mathrm{Ct}=$ cycle threshold, the thermocycle in which fluorescence statistically exceeds background levels, indicating a positive reaction.

${ }^{\mathrm{c}}$ Extract diluted 10-fold with sterile molecular biology-grade water.

\section{Interpretation for Table 1}

Controls. The negative and positive controls reacted as expected in each assay, indicating each as a valid assay. No amplification was observed in negative controls (rxn 1 and 7). Positive controls (rxn 2 and 8 ) each gave a positive reaction before 30 cycles; the difference in $\mathrm{Ct}$ value between the first and second assay is attributable to normal variation among runs.

Sample WM3-1,44. A positive reaction was observed in the undiluted extract (rxn 3), consistent with the hypothesis that this plant is infected with Serratia marcesens. Note that the sample extract did induce some PCR inhibition. This is suggested by the fact that the $\mathrm{Ct}$ for the tube containing the sample extract "spiked" with known DNA (rxn 4, the parallel control) was 11 cycles higher than the $\mathrm{Ct}$ for the tube receiving known DNA alone ( $\mathrm{rxn} 2$, the positive control); one expects the $\mathrm{Ct}$ value of the parallel control to be at least as low as that of the positive control. Dilution of the sample 10-fold substantially improved amplification (compare rxn 8 to rxn 10). Although dilution of the sample reduced the DNA concentration 10-fold, it also reduced the concentration of inhibitors 10-fold, permitting more efficient amplification.

Sample WM47. The undiluted DNA extract of this sample reacted negatively in 40 cycles of amplification (rxn 5), suggesting the plant was free of infection by S. marcesens. However, as in Sample WM3-1,44, there was evidence of PCR inhibition (compare Ct values for rxn 2 and rxn 6). As in Sample WM3-1,44, dilution of this sample improved PCR efficiency (compare rxns 12 and 8). In this case, this improvement in amplification efficiency allowed detection of a weak positive (rxn 11) that escaped detection in the undiluted DNA extract (rxn 5). 
need for staff support, can quickly become practical limitations for some plant diagnostic labs.

NA-based tests are generally considered to be rapid pathogen-detection tests, and indeed, the application of these may be rapid if a laboratory is implementing a USDA-approved standard protocol for a high-consequence pathogen or using a particular technique employed routinely in the lab. However, the ramp-up time for other test protocols, such as initial implementation of a protocol published in a research paper, can sometimes be significant. This is especially true if one must obtain live reference cultures from an outof-state laboratory as sources of genomic DNA for positive controls. Since many phytopathogens are in private collections of researchers and there is no central database on culture collections, it can be timeconsuming to identify a researcher who has cultures suitable for reference strains and who is willing to take the time to prepare and send such cultures. After identifying a source of reference cultures, one must also allow for the time to apply for and receive the appropriate USDA-APHISPPQ permit, although the new ePermits electronic permitting system has significantly improved this process. In order to avoid unnecessary investments of time and duplication of effort, it makes sense to consider whether diagnostic laboratories would be well-served to develop multistate cooperative agreements, with different laboratories investing the time, energy, and resources to develop competence with NA-based detection of different pathogens. Such multi-state cooperative arrangements should exclude high-consequence pathogens of regulatory or biosecurity concern, since expertise for detecting those pathogens is best distributed among several laboratories within the National Plant Diagnostic Network so that sample surges associated with a specific new threat could be handled in a timely way (94).

Most NA-based tests are by their nature designed to detect known pathogens. They are therefore not well-suited for detection of uncharacterized pathogenic agents, whereas biological tests (isolation, inoculation) are more likely to do so (82). In cases where a new pathogen is suspected, applied plant pathologists should rely on appropriate traditional techniques, at least initially. And, of course, the "gold standard" for involvement of a microorganism with a disease is the completion of Koch's postulates (1). However, once one has evidence of the involvement of a new pathogen, NA-based tests can and should be integral to pathogen characterization (for example, by determining the ITS sequences as part of the body of evidence in support of one's species determination).

Diagnosticians should think of each PCR test as an experiment designed to test the hypothesis that the pathogen of interest is associated with the diseased tissue. As in all experimentation, each PCR assay must have the proper controls in order to interpret test results correctly.

Laboratory tests alone-no matter how sophisticated-do not constitute diagnosis. A positive result via an NA-based test supports the hypothesis of association of the suspect microorganism with the diseased host tissue, the first step in Koch's postulates. However, association does not imply causality; detection is not the same as diagnosis. The presence of a known pathogen does not mean that the organism caused the particular syndrome being observed, a fact well-understood by experienced diagnosticians. Multiple pathogens, secondary organisms, and abiotic stressors may be present on growing plants, especially those in the field, but which is the ultimate threat to plant health in the current situation? Furthermore, avirulent isolates of known pathogens may be present on tissue diseased from some other factor that induces somewhat similar symptoms (77). In such cases, a positive result in an NA-based test could be misleading, since relatively few current NA-based detection protocols distinguish virulent from avirulent isolates (although this limitation applies to other pathogen-detection techniques, as well). The importance of the professional judgment of a diagnostician cannot be underestimated, as a good diagnostician will sort through the evidence and arrive at a diagnosis consistent with the plant disease "signature" presented by a particular case (89). Indeed, although the phrase "molecular diagnostics" is convenient and well-established in the clinical as well as plant-pathological literature, it is more appropriate to refer to NA-based tests as tools for "molecular detection".

\section{Selected Emerging Technologies}

PCR/electrospray ionization-mass spectrometry (PCR/ESI-MS; previously known as "TIGER", an acronym referring to Triangulation Identification for the Genetic Evaluation of Risks) is a new technique for rapid identification of microorganisms in environmental samples $(40,105)$. It is based on the use of mass spectrometry to characterize the base compositions of PCR products generated using a suite of conserved primers. For species determinations, the resulting base compositions are compared to a database of microbial basecomposition signatures. In contrast to probe-based detection of microorganisms, mass spectrometry does not require one to anticipate and test for particular microorganisms (40). Although use of this technique for identification of plant pathogens is under research and development (74), it seems unlikely that many plant pathology laboratories that do diagnostics and applied research in universities, state governments, and industry would have sufficient funds to purchase, staff, and operate such a facility. Selected federal laboratories may use this technology, and it is possible that a commercial enterprise could emerge that specializes in providing such a service nationally.

While not NA-based techniques, two novel microbial detection technologies deserve mention. In CANARY (Cellular Analysis and Notification of Antigen Risks and Yields), B lymphocytes previously engineered to produce a cytolsolic bioluminescent protein are transfected with a plasmid containing a gene coding for a membrane-bound, pathogen-specific antibody (81). When these cells are exposed to the target pathogen, they emit light within seconds. CANARY offers a combination of speed and sensitivity not available with current immunoassays nor with PCR-based protocols, detecting as little as $50 \mathrm{CFU}$ of some bacteria within seconds (81). An even more sensitive technique has emerged that is based on immunoassay (114). Silica-based nanoparticles are filled with a fluorescent dye and conjugated to an antibody specific to a surface antigen of the microbe of interest. The fluorescence of a single bacterial cell has been sufficient for detection using this technique (114). CANARY has been applied to plant pathogens (65), but to our knowledge, bioconjugated nanoparticles have not yet been used to detect plant pathogens.

\section{Conclusion}

NA-based pathogen detection techniques offer an increasing selection of tools for addressing disease problems currently of concern in applied plant pathology programs. Implementation of molecular tools today also builds the laboratory infrastructure and technical capacity to respond to new threats as they emerge. Sound implementation of any pathogendetection technique requires an understanding of its limitations, no less for NAbased techniques than for other techniques. Rigorous application of the appropriate controls is requisite when using NA-based tools. Furthermore, respect for the value and role of traditional laboratory techniques - and for obtaining multiple lines of evidence in crucial cases-is essential to the critical application of these tools.

\section{Acknowledgments}

Thanks are expressed to John R. Hartman, to an anonymous reviewer for providing helpful comments on a presubmission draft, and to an anonymous reviewer for a thorough and constructive review of the submitted version of the manuscript.

\section{Literature Cited}

1. Agrios, G. 2004. Plant Pathology. 5th ed. Elsevier, Burlington, MA.

2. Alvarez, A. 2004. Integrated approaches for detection of plant pathogenic bacteria and diagnosis of bacterial diseases. Annu. Rev. Phytopathol. 42:339-366.

3. Andrés, O., Rönn, A.-C., Ferrando, A., 
Bosch, M., and Domingo-Roura, X. 2006. Sequence quality is maintained after multiple displacement amplification of non-invasively obtained macaque semen DNA. Biotechnol. J. 1:466-469.

4. Atallah, Z. K., and Stevenson, W. R. 2006. A methodology to detect and quantify five pathogens causing potato tuber decay using real-time quantitative polymerase chain reaction. Phytopathology 96:1037-1045.

5. Bereswill, S., Bugert, P., Völksch, B., Ullrich, M., Bender, C. L., and Geider, K. 1994. Identification and relatedness of coronatine-producing Pseudomonas syringae pathovars by PCR analysis and sequence determination of the amplification products. Appl. Environ. Microbiol. 60:2924-2930.

6. Berg, T., Tesoriero, L., and Hailstones, D. L. 2005. PCR-based detection of Xanthomonas campestris pathovars in Brassica seed. Plant Pathol. 54:416-427.

7. Blomquist, C., Irving, T., Osterbauer, N., and Reeser, P. 2005. Phytophthora hibernalis: A new pathogen on Rhododendron and evidence of cross amplification with two PCR detection assays for Phytophthora ramorum. Online. Plant Health Progress doi:10.1094/ PHP-2005-0728-01-HN.

8. Bonants, P., Hagenaar-de Weerdt, M., van Gent-Pelzer, M., Lacourt, I., Cooke, D., and Duncan, J. 1997. Detection and identification of Phytophthora fragariae Hickman by the polymerase chain reaction. Eur. J. Plant Pathol. 103:345-355.

9. Bowers, J. H., Martin, F. N., Tooley, P. W., and Luz, E. D. M. N. 2007. Genetic and morphological diversity of temperate and tropical isolates of Phytophthora capsici. Phytopathology 97:492-503.

10. Bridge, P. D., and Arora, D. K. 1998. Interpretation of PCR methods for species definition. Pages 63-84 in: Applications of PCR in Mycology. P. D. Bridge, D. K. Arora, C. A. Reddy, and R. P. Elander, eds. CAB International, New York.

11. Bulluck, R., Shiel, P., Berger, P., Kaplan, D., Parra, G., Li, W., Levy, L., Keller, J., Reddy, M., Sharma, N., Dennis, M., Stack, J., Pierzynski, J., O’Mara, J., Webb, C., Finley, L., Lamour, K., McKemy, J., and Palm, M. 2006. A comparative analysis of detection techniques used in US regulatory programs to determine presence of Phytophthora ramorum in Camellia japonica 'Nucio's Gem' in an infested nursery in Southern California. Online. Plant Health Progress doi:10.1094/PHP2006-1016-01-RS.

12. Call, D. R. 2005. Challenges and opportunities for pathogen detection using DNA microarrays. Crit. Rev. Microbiol. 31:91-99.

13. Chilvers, M. I., du Toit, L. J., Akamatsu, H., and Peever, T. L. 2007. A real-time, quantitative PCR seed assay for Botrytis spp. that cause neck rot of onion. Plant Dis. 91:599-608.

14. Cockerill, F. R., and Uhl, J. R. 2002. Applications and challenges of real-time PCR for the clinical microbiology laboratory. Pages 3-27 in: Rapid Cycle Real-Time PCR-Methods and Applications: Microbiology and Food Analysis. U. Reischl, C. Wittwer, and F. R. Cockerill, eds. Springer-Verlag, Berlin, Germany.

15. Cooke, D. E. L., Drenth, A., Duncan, J. M., Wagels, G., and Brasier, C. M. 2000. A molecular phylogeny of Phytophthora and related oomycetes. Fungal Genet. Biol. 30:1732.

16. Cooke, D. E. L., Duncan, J. M., Williams, N. A., Hagenaar-de Weerdt, M., and Bonants, P. M. J. 2000. Identification of Phytophthora species on the basis of restriction fragment analysis of the internal transcribed spacer regions of ribosomal DNA. Bull. OEPP/EPPO $30 \cdot 519-523$
17. Cubero, J., and Graham, J. H. 2002. Genetic relationship among worldwide strains of Xanthomonas causing canker in citrus species and design of new primers for their identification by PCR. Appl. Environ. Microbiol. 68:12571264.

18. Cunnington, J. H., Takamatsu, S., Lawrie, A. D., and Pascoe, I. G. 2003. Molecular identification of anamorphic powdery mildews (Erysiphales). Australas. Plant Pathol. 32:421-428.

19. Cuppels, D. A., Louws, F. J., and Ainsworth, T. 2006. Development and evaluation of PCR-based diagnostic assays for the bacterial speck and bacterial spot pathogens of tomato. Plant Dis. 90:451-458.

20. Dan, H., Ali-Khan, S. T., and Robb, J. 2001. Use of quantitative PCR diagnostics to identify tolerance and resistance to Verticillium dahliae in potato. Plant Dis. 85:700-705.

21. Davidson, J. M., Werres, S., Garbelotto, M. Hansen, E. M., and Rizzo, D. M. 2003. Sudden oak death and associated diseases caused by Phytophthora ramorum. Online. Plant Health Progress doi:10.1094/PHP-20030707-01-DG.

22. Dean, F. B., Hosono, S., Fang, L., Wu, X., Faruqi, A. F., Bray-Ward, P., Sun, Z., Zong,

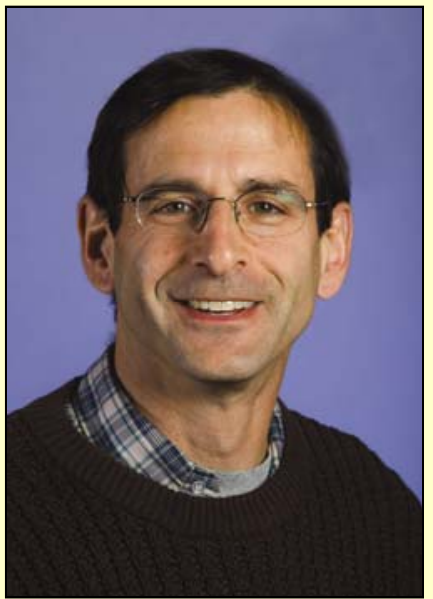

Paul Vincelli

Dr. Vincelli, Extension Professor and Provost's Distinguished Service Professor, has worked as a member of the Extension Plant Pathology team at the University of Kentucky since 1990. $\mathrm{He}$ teaches introductory plant pathology and provides Extension programming on the pathology of forage crops, turfgrasses, corn, and organic crops. His M.S. and Ph.D. degrees in plant pathology are from Rutgers University (1983) and Cornell University (1988), respectively. His professional service includes work as a Peace Corps Volunteer in Nicaragua and Colombia, as well as 2 years as the Extension Plant Pathologist at the University of Wyoming. Dr. Vincelli's initiation into nucleic acid-based detection techniques began while on sabbatical in 1998 in the laboratory of Jo Handelsman at the University of Wisconsin where, after subjecting him to a suitable number of failures, the PCR gods smiled upon him.
Q., Du, Y., Du, J., Driscoll, M., Song, W., Kingsmore, S. F., Egholm, M., and Lasken, R. S. 2002. Comprehensive human genome amplification using multiple displacement amplification. Proc. Natl. Acad. Sci. 99:52615266.

23. Delanoy, M., Salmon, M., Kummert, J., Frison, E., and Lepoivre, P. 2003. Development of real-time PCR for the rapid detection of episomal Banana streak virus (BSV). Plant Dis. 87:33-38.

24. Edel, V. 1998. Polymerase chain reaction in mycology: An overview. Pages 1-20 in: Applications of PCR in Mycology. P. D. Bridge, D. K. Arora, C. A. Reddy, and R. P. Elander, eds. CAB International, New York.

25. Elphinstone, J. G., Hennessy, J., Wilson, J. K., and Stead, D. E. 1996. Sensitivity of different methods for the detection of Ralstonia solanacearum in potato tuber extracts. EPPO Bull. 26:663-678.

26. Espy, M. J., Uhl, J. R., Sloan, L. M., Buckwalter, S. P., Jones, M. F., Vetter, E. A., Yao, J. D. C., Wengenack, N. L., Rosenblatt, J. E. Cockerill, F. R., III, and Smith, T. F. 2006. Real-Time PCR in clinical microbiology: Applications for routine laboratory testing. Clin. Microbiol. Rev. 19:165-256.

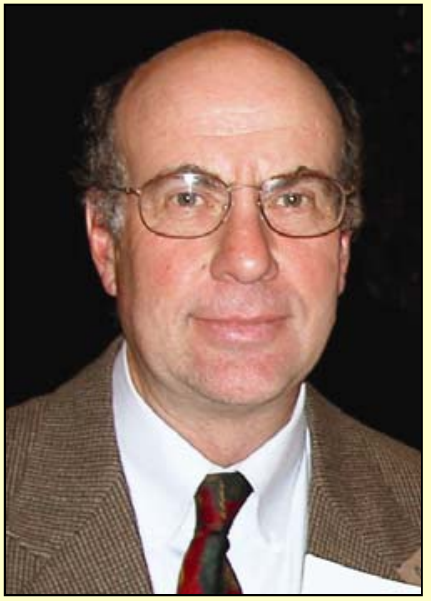

Ned Tisserat

Dr. Tisserat received his B.S. from Colorado State University, his M.S from Texas A\&M University, and a Ph.D. from the University of WisconsinMadison in plant pathology. Currently, he is an extension specialist and professor in the Department of Bioagricultural Sciences and Pest Management at Colorado State University. His research includes studies on the biology and management of turfgrass, tree, ornamental, and small grain diseases. His research group is currently studying snow molds of turfgrasses caused by Typhula species and necrotic ring spot, a common and damaging disease of Kentucky bluegrass lawns in the Rocky Mountain region. Ned is associate director of the Great Plains Diagnostic Network and is involved in developing molecular mark ers, electronic diagnostic keys, and sentinel plants for high-consequence plant pathogens. 
27. Fatmi, M., Damsteegt, V. D., and Schaad, N. W. 2005. A combined agar-absorption and BIO-PCR assay for rapid, sensitive detection of Xylella fastidiosa in grape and citrus. Plant Pathol. 54:1-7.

28. Fessehaie, A., De Boer, S. H., and Lévesque, C. A. 2003. An oligonucleotide array for the identification and differentiation of bacteria pathogenic on potato. Phytopathology 93: 262-269.

29. Flowers, J. L., Hartman, J. R., and Vaillancourt, L. J. 2006. Histology of Diplodia pinea in diseased and latently infected Pinus nigra shoots. For. Pathol. 36:447-459.

30. Frederick, R. D., Snyder, C. L., Peterson, G. L., and Bonde, M. R. 2002. Polymerase chain reaction assays for the detection and discrimination of the soybean rust pathogens Phakopsora pachyrhizi and P. meibomiae. Phytopathology 92:217-227.

31. Frederick, R. D., Snyder, K. E., Tooley, P. W., Berthier-Schaad, Y., Peterson, G. L., Bonde, M. R., Schaad, N. W., and Knorr, D. A. 2000. Identification and differentiation of Tilletia indica and T. walkeri using the polymerase chain reaction. Phytopathology 90:951-960.

32. Garzón, C. D., Geiser, D. M., and Moorman, G. W. 2005. Diagnosis and population analysis of Pythium species using AFLP fingerprinting. Plant Dis. 89:81-89.

33. Gonzalez, J. M., Portillo, M. C., and SaizJimenez, C. 2005. Multiple displacement amplification as a pre-polymerase chain reaction (pre-PCR) to process difficult to amplify samples and low copy number sequences from natural environments. Environ. Microbiol. 7:1024-1028.

34. Grey, B. E., and Steck, T. R. 2001. The viable but nonculturable state of Ralstonia solanacearum may be involved in long-term survival and plant infection. Appl. Environ. Microbiol. 67:3866-3872.

35. Guillemette, T., Iacomi-Vasilescu, B., and Simoneau, P. 2004. Conventional and realtime PCR-based assay for detecting pathogenic Alternaria brassicae in cruciferous seed. Plant Dis. 88:490-496.

36. Gundersen, D. E., and Lee, I.-M. 1996. Ultrasensitive detection of phytoplasmas by nested-PCR assays using two universal primer pairs. Phytopathol. Mediterr. 35:144151.

37. Hajibabaei, M., Singer, G. A. C., Hebert, P. D. N., and Hickey, D. A. 2007. DNA barcoding: How it complements taxonomy, molecular phylogenetics, and population genetics. Trends Genet. 4:167-171.

38. Harmon, P. F., Dunkle, L. D., and Latin, R. 2003. A rapid PCR-based method for the detection of Magnaporthe oryzae from infected perennial ryegrass. Plant Dis. 87:1072-1076.

39. Henson, J. M., and French, R. 1993. The polymerase chain reaction and plant disease diagnosis. Annu. Rev. Phytopathol. 31:81-109.

40. Hofstadler, S. A., Sampath, R., Blyn, L. B., Eshoo, M. W., Hall, T. A., Jiang, Y., Drader, J. J., Hannis, J. C., Sannes-Lowery, K. A., Cummins, L. L., Libby, B., Walcott, D. J., Schink, A., Massire, C., Ranken, R., Gutierrez, J., Manalili, S., Ivy, C., Melton, R., Levene, H., Barrett-Wilt, G., Li, F., Zapp, V., White, N., Samant, V., McNeil, J. A., Knize, D., Robbins, D., Rudnick, K., Desai, A., Moradi, E., and Ecker, D. J. 2005. TIGER: The universal biosensor. Int. J. Mass Spectrometry 242:2341.

41. Hogg, A. C., Johnston, R. H., and Dyer, A. T. 2007. Applying real-time quantitative PCR to Fusarium crown rot of wheat. Plant Dis. 91:1021-1028.

42. Hughes, K. J. D., Tomlinson, J. A., Griffin, R. L., Boonham, N., Inman, A. J., and Lane, C. R. 2006. Development of a one-step real-time polymerase chain reaction assay for diagnosis of Phytophthora ramorum. Phytopathology 96:975-981.

43. Iriarte, F. B., Wetzel, H. C., III, Fry, J. D., Martin, D. L., and Tisserat, N. A. 2004. Genetic diversity and aggressiveness of Ophiosphaerella korrae, a cause of spring dead spot of bermudagrass. Plant Dis. 88:13411386.

44. Janse, J. D. 1988. A detection method for Pseudomonas solanacearum in symptomless potato tubers and some data on its sensitivity and specificity. EPPO Bull. 18:343-351.

45. Ji, P., Allen, C., Sanchez-Perez, A., Yao, J., Elphinstone, J. G., Jones, J. B., and Momol, M. T. 2007. New diversity of Ralstonia solanacearum strains associated with vegetable and ornamental crops in Florida. Plant Dis. 91:195-203.

46. Kerkoud, M., Manceau, C., and Paulin, J.-P. 2002. Rapid diagnosis of Pseudomonas syringae pv. papulans, the causal agent of blister spot of apple, by polymerase chain reaction using specifically designed $h r p L$ gene primers. Phytopathology 92:1077-1083.

47. Kim, Y-s., Dixon, E. W., Vincelli, P., and Farman, M. L. 2003. Field resistance to strobilurin $\left(\mathrm{Q}_{0} \mathrm{I}\right)$ fungicides in Pyricularia grisea caused by mutations in the mitochondrial cytochrome b gene. Phytopathology 93:891900.

48. Kiss, L., Takamatsu, S., and Cunnington, J. H. 2005. Molecular identification of Oidium neolycopersici as the causal agent of the recent tomato powdery mildew epidemics in North America. Plant Dis. 89:491-496.

49. Kreader, C. A. 1996. Relief of amplification inhibition in PCR with bovine serum albumin or T4 gene 32 protein. Appl. Environ. Microbiol. 62:1102-1106.

50. Kubota, R., Alvarez, A. M., Vine, B. G., and Jenkins, D. M. 2007. Development of a loopmediated isothermal amplification method (LAMP) for detection of the bacterial wilt pathogen Ralstonia solanacearum. (Abstr.) Phytopathology 97:S60.

51. Leite, R. P., Minsavage, G. V., Bonas, U., and Stall, R. E. 1994. Detection and identification of pathogenic Xanthomonas strains by amplification of DNA sequences of hrp genes of Xanthomonas campestris pv. vesicatoria. Appl. Environ. Microbiol. 60:1068-1077.

52. Lievens, B., Brouwer, M., Vanachter, A. C. R. C., Levesque, C. A., Cammue, B. P. A., and Thomma, B. P. H. J. 2003. Design and development of a DNA array for rapid detection and identification of multiple tomato vascular wilt pathogens. FEMS Microbiol. Lett. 223:113-122.

53. Lievens, B., Grauwet, T. J. M. A., Cammue, B. P. A., and Thomma, B. P. J. H. 2005. Recent developments in diagnostics of plant pathogens: A review. Recent Res. Devel. Microbiol. 9:1-23.

54. Lievens, B., and Thomma, B. P. H. J. 2005. Recent developments in pathogen detection arrays: Implications for fungal plant pathogens and use in practice. Phytopathology 95:1374-1380

55. Linderman, R. G., and Davis, E. A. 2006. Survival of Phytophthora ramorum compared to other species of Phytophthora in potting media components. HortTechnology 16:502507.

56. Louws, F. J., Rademaker, J. L. W., and Bruijn, F. J. 1999. The three Ds of PCR-based genomic analysis of phytobacteria: Diversity, detection, and disease diagnosis. Annu. Rev. Phytopathol. 37:81-125.

57. Malvick, D. K., and Grunden, E. 2005. Isolation of fungal DNA from plant tissues and removal of DNA amplification inhibitors. Mol. Ecol. Notes 5:958-960.

58. Martin, F. N., and Tooley, P. W. 2003. Phylogenetic relationships among Phytophthora species inferred from sequence analysis of mitochondrially encoded cytochrome oxidase I and II genes. Mycologia 95:269-284.

59. Martin, F. N., and Tooley, P. W. 2004. Identification of Phytophthora isolates to species level using restriction fragment length polymorphism analysis of a polymerase chain reaction-amplified region of mitochondrial DNA. Phytopathology 94:983-991.

60. Martin, R. R., James, D., and Lévesque, C. A. 2000. Impacts of molecular diagnostic technologies on plant disease management. Annu. Rev. Phytopathol. 38:207-239.

61. Mavrodieva, V., Levy, L., and Gabriel, D. W. 2004. Improved sampling methods for realtime polymerase chain reaction diagnosis of citrus canker from field samples. Phytopathology 94:61-68.

62. McCartney, H. A., Foster, S. J., Fraaije, B. A., and Ward, E. 2003. Molecular diagnostics for fungal plant pathogens. Pest Manag. Sci. 59:129-142

63. Min, X. J., and Hickey, D. A. 2007. Assessing the effect of varying sequence length on DNA barcoding of fungi. Mol. Ecol. Notes 7:365 373.

64. Mumford, R., Boonham, N., Tomlinson, J., and Barker, I. 2006. Advances in molecular diagnostics - new solutions for old problems. Eur. J. Plant Pathol. 116:1-19.

65. Nargi, F. 2006. CANARY B-cell sensor for rapid identification of plant pathogens. (Abstr.) Phytopathology 96:S83.

66. Nogva, H. K., Drømtorp, S. M., Nissen, H., and Rudi, K. 2003. Ethidium monoazide for DNA-based differentiation of viable and dead bacteria by $5^{\prime}$-nuclease PCR. BioTechniques 34:804-813.

67. Notomi, T., Okayama, H., Masubuchi, H., Yonekawa, T., Watanabe, K., Amino, N., and Hase, T. 2000. Loop-mediated isothermal amplification of DNA. Nucleic Acids Res. 28, e63.

68. Obradovic, A., Mavridis, A., Rudolph, K., Janse, J. D., Arsenijevic, M., Jones, J. B., Minsavage, G. V., and Wang, J. F. 2004. Characterization and PCR-based typing of Xanthomonas campestris pv. vesicatoria from peppers and tomatoes in Serbia. Eur. J. Plant Pathol. 110:285-292.

69. Overbergh, L., Giulietti, A., Valckx, D., and Mathieu, C. 2005. Real-time polymerase chain reaction. Pages 109-125 in: Molecular Diagnostics. G. P. Patrinos and W. Ansorge, eds. Elsevier, Amsterdam.

70. Ozakman, M., and Schaad, N. W. 2003. A real-time BIO-PCR assay for detection of Ralstonia solanacearum race 3 , biovar 2 , in asymptomatic potato tubers. Can. J. Plant Pathol. 25:232-239.

71. Pearce, D. A. 1998. PCR as a tool for the investigation of seed-borne disease. Pages 309-324 in: Applications of PCR in Mycology, P. D. Bridge, D. K. Arora, C. A. Reddy, and R. P. Elander, eds. CAB International, New York

72. Peres, N. A., Harakava, R., Carroll, G. C. Adaskaveg, J. E., and Timmer, L. W. 2007. Comparison of molecular procedures for detection and identification of Guignardia citricarpa and G. mangiferae. Plant Dis. 91:525531

73. Pinard, R., de Winter, A., Sarkis, G. J., Gerstein, M. B., Tartaro, K. R., Plant, R. N., Egholm, M., Rothberg, J. M., and Leamon, J. H. 2006. Assessment of whole genome amplification-induced bias through high-throughput, massively parallel whole genome sequencing. BMC Genomics 7:216.

74. Postnikova, E., Baldwin, C., Whitehouse, C. A., Sechler, A., Schaad, N., Sampath, R., Harpin, V., Li, F., Melton, R., Blin, L. Drader, J., Hofstadler, S., and Schneider, W. L. 2007. Detection and identification of phy- 
tobacteria using PCR/electrospray inonization-mass spectrometry. (Abstr.) Phytopathology 97:S94.

75. Powers, T. 2006. Nematode molecular diagnostics: From bands to barcodes. Annu. Rev. Phytopathol. 42:367-383.

76. Proffer, T. J., Berardi, R., Ma, Z., Nugent, J. E., Ehret, G. R., McManus, P. S., Jones, A. L., and Sundin, G. W. 2006. Occurrence, distribution, and polymerase chain reactionbased detection of resistance to sterol demethylation inhibitor fungicides in populations of Blumeriella jaapii in Michigan. Phytopathology 96:709-717.

77. Putnam, M. L., and Miller, M. L. 2007. Rhodococcus fascians in herbaceous perennials. Plant Dis. 91:1064-1076.

78. Qi, M., and Yang, Y. 2002. Quantification of Magnaporthe grisea during infection of rice plants using real-time polymerase chain reaction and northern blot/phosphoimaging analyses. Phytopathology 92:870-876.

79. Rachdawong, S., Cramer, C. L., Grabau, E. A., Stromberg, V. K., Lacy, G. H., and Stromberg, E. L. 2002. Gaeumannomyces graminis vars. avenae, graminis, and tritici identified using PCR amplification of avenacinase-like genes. Plant Dis. 86:652-660.

80. Rico, A., Lopéz, R., Asensio, C., Aizpún, M. T., Asensio-S.-Manzanera, M. C., and Murillo, J. 2003. Nontoxigenic strains of Pseudomonas syringae pv. phaseolicola are a main cause of halo blight of beans in Spain and escape current detection methods. Phytopathology 93:1553-1559.

81. Rider, T. H., Petrovick, M. S., Nargi, F. E., Harper, J. D., Schwoebel, E. D., Mathews, R. H., Blanchard, D. J., Bortolin, L. T., Young, A. M., Chen, J., and Hollis, M. A. 2003. A B cell-based sensor for rapid identification of pathogens. Science 301:213-215.

82. Rowhani, A., Uyemoto, J. K., Golino, D. A., and Martelli, G. P. 2005. Pathogen testing and certification of Vitis and Prunus species. Annu. Rev. Phytopathol. 43:261-278.

83. Rudi, K., Moen, B., Drømtorp, S. M., and Holck, A. L. 2005. Use of ethidium monoazide and PCR in combination for quantification of viable and dead cells in complex samples. Appl. Environ. Microbiol. 71:10181024

84. Schaad, N. W., Berthier-Schaad, Y., Sechler, A., and Knorr, D. 1999. Detection of Clavibacter michiganensis subsp. michiganensis in potato tubers by BIO-PCR and an automated real-time fluorescence detection system. Plant Dis. 83:1095-1100.

85. Schaad, N. W., Frederick, R. D., Shaw, J., Schneider, W. L., Hickson, R., Petrillo, M., and Luster, D. G. 2003. Advances in molecular-based diagnostics in meeting crop biosecurity and phytosanitary issues. Annu. Rev. Phytopathol. 41:305-324.

86. Schaad, N. W., Opgenorth, D., and Gaush, P. 2002. Real-time polymerase chain reaction for one-hour on-site diagnosis of Pierce's disease of grape in early season asymptomatic vines. Phytopathology 92:721-728.

87. Scortichini, M., Marchesi, U., Dettori, M. T., and Rossi, M. P. 2003. Genetic diversity, presence of the $s y r B$ gene, host preference and virulence of Pseudomonas syringae pv. syringae strains from woody and herbaceous host plants. Plant Pathol. 52:277-286.

88. Seal, S. E., Taghavi, M., Fegan, N., Hayward, A. C., Fegan, M. 1999. Determination of Ralstonia (Pseudomonas) solanacearum rDNA subgroups by PCR tests. Plant Pathol. 48:115-120.

89. Shurtleff, M. C., and Averre, C. W., III. 1997. The Plant Disease Clinic and Field Diagnosis. American Phytopathological Society, St. Paul, MN

90. Singleton, P. 2000. DNA Methods in Clinical Microbiology. Kluwer Academic Publishers, Boston.

91. Skantar, A. M., and Carta, L. K. 2005. Multiple displacement amplification (MDA) of total genomic DNA from Meloidogyne spp. and comparison to crude DNA extracts in PCR of ITS1, 28S D2-D3 rDNA and Hsp90. Nematology 7:285-293.

92. Song, W. Y., Kim, H. M., Hwang, C. Y., and Schaad, N. W. 2004. Detection of Acidovorax avenae ssp. avenae in rice seeds using BIOPCR. J. Phytopathol. 152:667-676.

93. Sorensen, K., Kim, K.-H., and Takemoto, J. Y. 1998. PCR detection of cyclic lipodepsinonapeptide-producing Pseudomonas syringae pv. syringae and similarity of strains. Appl. Environ. Microbiol. 64:226-230.

94. Stack, J., Cardwell, K., Hammerschmidt, R., Byrne, J., Loria, R., Snover-Clift, K., Baldwin, W., Wisler, G., Beck, H., Bostock, R., Thomas, C., and Luke, E. 2006. The national plant diagnostic network. Plant Dis. 90:128136

95. Stanton, J., Hugall, A., and Moritz, C. 1997. Nucleotide polymorphisms and an improved PCR-based mtDNA diagnostic for parthenogenetic root-knot nematodes (Meloidogyne spp.). Fundam. Appl. Nematol. 20:261-268.

96. Summerell, B. A., Salleh, B., and Leslie, J. F. 2003. A utilitarian approach to Fusarium identification. Plant Dis. 87:117-128.

97. Swanson, J. K., Montes, L., Mejia, L., and Allen, C. 2007. Detection of latent infections of Ralstonia solanacearum race 3 biovar 2 in geranium. Plant Dis. 91:828-834

98. Szalanski, A. L., Sui, D. D., Harris, T. S., and Powers, T. O. 1997. Identification of cyst nematodes of agronomic and regulatory concern with PCR-RFLP of ITS1. J. Nematol. 29:255-267.

99. Tambong, J. T., de Cock, A. W. A. M., Tinker, N. A., and Lévesque, C. A. 2006. Oligonucleotide array for identification and detection of Pythium Species. Appl. Environ. Microbiol. 72:2691-2706.

100. Tisserat, N. A., Hulbert, S. H., and Sauer, K. M. 1994. Selective amplification of rDNA internal transcribed spacer regions to detect Ophiosphaerella korrae and $O$. herpotricha. Phytopathology 84:478-482.

101. Tooley, P. W., Goley, E. D., Carras, M. M., and O'Neill, N. R. 2002. AFLP comparisons among Claviceps africana isolates from the United States, Mexico, Africa, Australia, India, and Japan. Plant Dis. 86:1247-1252.

102. Tooley, P. W., Martin, F. N., Carras, M. M., and Frederick, R. D. 2006. Real-time fluorescent polymerase chain reaction detection of Phytophthora ramorum and Phytophthora pseudosyringae using mitochondrial gene re- gions. Phytopathology 96:336-345

103. Tredway, L. P. 2006. Genetic relationships among Magnaporthe poae isolates from turforass hosts and relative susceptibility of 'Penncross' and 'Penn A-4' creeping bentgrass. Plant Dis. 90:1531-1538.

104. Tubajika, K. M., Bulluck, R., Shiel, P. J., Scott, S. E., and Sawyer, A. J. 2006. The oc currence of Phytophthora ramorum in nursery stock in California, Oregon, and Washington states. Online. Plant Health Progress doi:10.1094/PHP-2006-0315-02-RS.

105. Van Ert, M. N., Hofstadler, S. A., Jiamg, Y., Busch, J. D., Wagner, D. M., Drader, J. J. Ecker, D. J., Hannis, J. C., Huynh, L. Y. Schupp, J. M., Simonson, T. S., and Kiem, P. 2004. Mass spectrometry provides accurate characterization of two genetic marker types in Bacillus anthracis. BioTechniques 27:642651.

106. Ward, L. I., Beales, P. A., Barnes, A. V., and Lane, C. R. 2004. A real-time PCR assay based method for routine diagnosis of Spongospora subterranea on potato tubers. J. Phytopathol. 152:633-638

107. Weller, S. A., Elphinstone, J. G., Smith, N. C., Boonham, N., and Stead, D. E. 2000. Detection of Ralstonia solanacearum strains with a quantitative, multiplex, real-time, fluorogenic PCR (Taqman) assay. Appl. Environ. Microbiol. 66:2853-2858.

108. Wetzel, H. C., III. 1999. Geographic distribution and genetic diversity of three Ophio sphaerella species that cause spring dead spot of bermudagrass. Ph.D. thesis. Kansas State University, Manhattan

109. White, T. J., Bruns, T., Lee, S., and Taylor, J. W. 1990. Amplification and direct sequencing of fungal ribosomal RNA genes for phylogenetics. Pages 315-322 in: PCR Protocols: A Guide to Methods and Applications. M. A. Innis, D. H. Gelgard, J. J. Sninsky, and T. J. White, eds. Academic Press, New York.

110. Wiglesworth, M. D., Nesmith, W. C., Schardl, C. L., Li, D. X., and Siegel, M. R. 1994. Use of specific repetitive sequences in Peronospora tabacina for the early detection of the tobacco blue mold pathogen. Phytopathology: 84:425-430.

111. Wilson, I. G. 1997. Inhibition and facilitation of nucleic acid amplification. Appl. Environ. Microbiol. 63:3741-3751.

112. Zhang, A. W., Hartman, G. L., Curio-Penny, B., Pedersen, W. L., and Becker, K. B. 1999. Molecular detection of Diaporthe phaseolorum and Phomopsis longicola from soybean seeds. Phytopathology 89:796-804.

113. Zhang, Z. G., Li, Y. Q., Fan, H., Wang, Y. C. and Zheng, X. B. 2006. Molecular detection of Phytophthora capsici in infected plant tissues, soil and water. Plant Pathol. 55:770-

114. Zhao, X., Hilliard, L. R., Mechery, S. J., Wang, Y., Bagwe, R. P., and Jin, S. 2004. A rapid bioassay for single bacterial cell quantitation using bioconjugated nanoparticles Proc. Natl. Acad. Sci. 101(42):15027-15032.

115. Zhonghua, M., and Michailides, T. J. 2005. Advances in understanding molecular mechanisms of fungicide resistance and molecular detection of resistant genotypes in phytopathogenic fungi. Crop Prot. 24:853-863. 